\title{
Hydration change on complexation of aromatic ligands with DNA: molecular dynamics simulations
}

\author{
V. V. Kostjukov, N. M. Khomytova, M. P. Evstigneev
}

Sevastopol National Technical University

33, Universitetskaya Str, Sevastopol, Ukraine 99053

max_evstigneev@mail.ru

\begin{abstract}
Aim. Analysis of the hydration changes at formation of DNA complexes with biologically active aromatic compounds (BAC): antibiotics actinomycin D, daunomycin, nogalamycin, novantrone and mutagens ethidium bromide and proflavine. Methods. Molecular dynamics simulations. Results. The hydration indexes for double-helical DNA and ligands in a free and complexed states were calculated. A critical analysis of modern ideas about changing water environment at binding of aromatic ligands to DNA was performed. Conclusions. It is shown that upon binding of aromatic BAC with DNA a significant (from 2.6 for novantrone to 13.1 for actinomycin D) liberation of water molecules out of hydration shells with the disruption of hydrogen bonds takes place.
\end{abstract}

Keywords: double-helical DNA, aromatic ligand, hydration index, water release.

Introduction. Biologically active aromatic compounds (BAC) are widely used in chemotherapy of various diseases [1]. Medical and biological effect of the majority of BAC is based on their intercalation into nucleic acids and subsequent inhibition of the processes of replication and transcription of DNA and RNA in cells [1].

As the reactions of complexation of BAC with DNA and RNA occur in water environments, the interaction with water molecules (hydration) has

(C) Institute of Molecular Biology and Genetics NAS of Ukraine, 2010 considerable influence on their course. There is a lot of fundamental data (e.g. [2]) on the contribution of water environments into the stabilization of secondary structures of nucleic acids; however, the recent scientific literature still displays considerable interest to this issue. There are at least two explanations hereof for the class of DNA-binding BAC. Firstly, there is growing number of reports, evidencing that water environment may act as a regulator of specificity of ligand binding to DNA. The examples are an allosteric effect during binding of the antibiotic actinomycin $\mathrm{D}$ to 
DNA due to participation of water molecules [3]; destabilization of biologically vital DNA hairpins during ligand binding, caused by the change in structure of intramolecular water bridges [4]; considerably different hydration profiles of two similar antibiotics, daunomycin and doxorubicin, supposedly responsible for difference in their biological activity [5], etc.

The second explanation of the increased interest to the contribution of water environment during binding of low-molecular compounds to DNA is the fact that current views on the role of hydration for this class of ligands are rather contradictory. Two contradictory opinions are stated in the literature concerning the changes in hydration during complexation of ligands and DNA. The first opinion is based on an assumption that the complexation is accompanied with release of some water molecules bound to DNA (see review [6]). The second one is vice versa stating uptake of water molecules upon complexation (see review [7]). Such discrepancy of opinions does not allow a final conclusion about a role of water environment in complexation of ligands with DNA.

In the present work molecular dynamics (MD) simulation was used to calculate hydration upon binding of six BAC - DNA intercalators - to DNA, namely: anti-tumour antibiotics actinomycin D (AMD), daunomycin (DAU), nogalamycin (NOG), novantrone (NOV), and mutagens ethidium bromide (EB) and proflavine (PF) (Fig.1). The application of results, obtained in this research and in the previous work [8], makes it possible to analyze the abovementioned discrepancy.

Methods. Spatial structures of complexes. Self-complementary decamer d(GCGTCGACGC) ${ }_{2}$ was used as a model duplex of DNA both in the present work and previously [6, 8]. The spatial structure of DNA decamer, corresponding to B-form, was constructed using HyperChem 8.0. software. On intercalation of ligands their chromophores are inserted into the central CpG-site of the duplex. The spatial structures of investigated ligands were taken from Protein Data Bank [9]. The parameters of atoms and atom-atom interactions between DNA and ligands correspond to the AMBER force field for nucleic acids. The atomic charges and initial structures of the complexes are taken from the work [10].
The explicit account of water environment was performed using water molecules of the TIP3P model, placed into a cubic box with the edge length of $0.35 \mathrm{~nm}$ (1423 molecules). Neutralization of charges of DNA phosphates was conducted by $18 \mathrm{Na}^{+}$ions, placed 0.6 $\mathrm{nm}$ away from the atoms of phosphorus on bisectors of the angles O1P-P-O2P. Optimization of geometry of ligand-DNA complexes was conducted via minimization of potential energy by the method of conjugate gradients.

Molecular dynamics. MD calculation of ligands, DNA and their complexes in the process of thermal motion was performed using X-PLOR 3.1 software [11]. After minimization of potential energy, the MD procedure was conducted according to Verlet's algorithm with the time step $\Delta \mathrm{t}=2 \mathrm{fs}$ and SHAKE algorithm at constant temperature $\mathrm{T}=298 \mathrm{~K}$. The external water shell was fixed while modeling to prevent release of water molecules into vacuum. Free (non-fixed) water layer corresponded to the thickness of the adjacent hydration shell, i.e. to the bimolecular layer of $0.4 \mathrm{~nm}$ [12]. The total time of evolution was $2 \mathrm{~ns}$. The coordinates of all atoms were registered every 1 ps.

Hydrogen bonds with water. The averaged numbers of water molecules, forming hydrogen bonds with hydrophilic atoms $(\mathrm{N}, \mathrm{O})$ of DNA and BAC molecules, were calculated via trajectories of thermal motion during the last $40 \mathrm{ps}$ of MD simulations. The presence of a hydrogen bond was registered if distances between electronegative atoms of molecules and atoms of oxygen (hydrogen) of water did not exceed 0.32 $(0.24) \mathrm{nm}$, respectively [13]. Both types of forming $\mathrm{H}$-bond between the water molecule and dissolved substance were considered, namely, the one with the participation of atom of water hydrogen and water oxygen as a donor, and the other - with the participation of atom of DNA hydrogen (ligand) and water oxygen as an acceptor [14].

Quantitative evaluation of hydration. In the present work the hydration degree of ligand, DNA and their complex (C) was evaluated according to hydration index $N$, equal to the averaged number of water molecules, forming hydrogen bonds with hydrophilic atoms of the dissolved molecule in MD process. In this case a two-stage process of BAC intercalation into DNA was considered: local untwisting of DNA with 


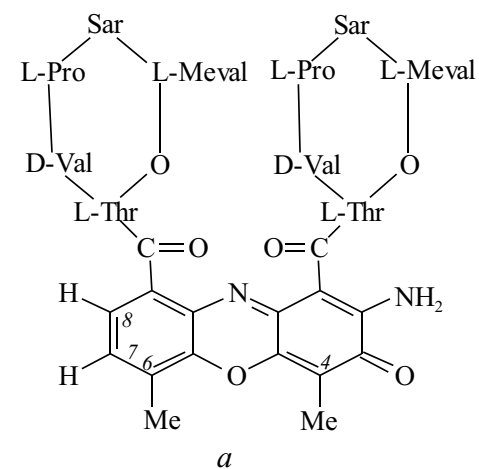

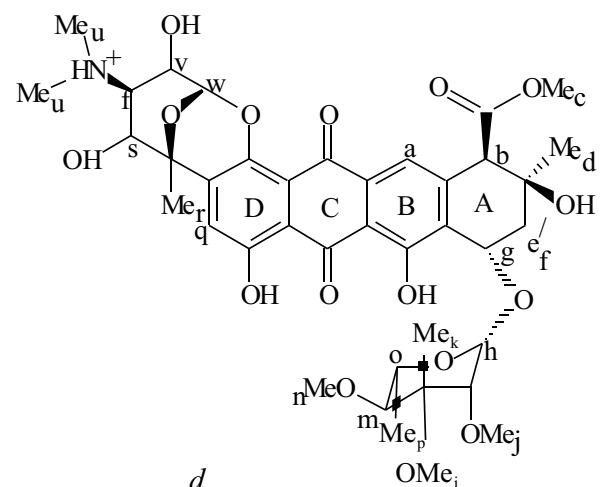
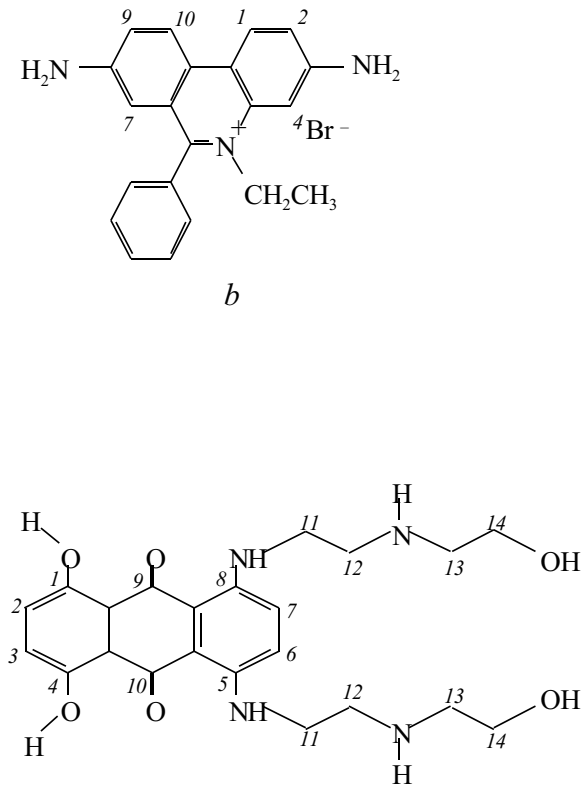

$e$

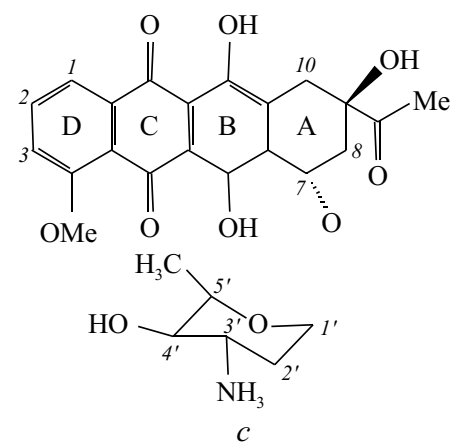

$\overbrace{5}^{2}$

$f$

Fig.1 Structures of aromatic ligands: actinomycin D $(a)$, ethidium bromide $(b)$, daunomycin $(c)$, nogalamycin $(d)$, novantrone $(e)$ and proflavine $(f)$

the formation of intercalation pocket (DNA*) and insertion of the ligand $(L)$ into it [15]:

$$
\begin{aligned}
& \text { DNA }>\text { DNA*; } \\
& \text { DNA }^{*}+L>C .
\end{aligned}
$$

Corresponding changes in hydration on the stages of untwisting $\Delta N_{u}$ and insertion $\Delta N_{i}$ and in the whole intercalation process $\Delta N$ were evaluated as follows:

$$
\begin{gathered}
\Delta N_{u}=N_{D N A^{*}}-N_{D N A} ; \\
\Delta N_{i}=N_{D N A-C}+N_{L-C}-N_{D N A^{*}}-N_{L} ; \\
\Delta N=\Delta N_{u}+\Delta N_{i},
\end{gathered}
$$

where $N_{D N A-C}$ and $N_{L-C}$-hydration indices of DNA and ligand in the complex, respectively.

Results and Discussion. In the present work the hydration index $N$, equal to the average number of water molecules, forming H-bonds with the hydrate-active groups of ligands, DNA or complexes in the process of system evolution in MD simulations, was used as a quantitative characteristic of the change in the nearest hydration layer upon complexation of aromatic ligands with DNA. The results of calculations of indices for all the considered ligands are presented in Table.

Hydration of free ligands and DNA. The hydration indices $N_{L}$ of ligands in free state are in good correspondence with their sizes and number of hydrophilic centres (Table and Fig.2). For instance, the lowest $N_{L}$ values are observed for small molecules of $\mathrm{EB}$ and $\mathrm{PF}$, containing only two amino-groups each. Also the presence of an additional imino-group in $\mathrm{PF}$ with positively charged atom $\mathrm{N}^{+}$conditioned rather higher value of $N_{L}$. It should be noted that AMD molecule with two bulky penta-peptide rings, containing a large number of keto- and imino-groups, is even less hydrated in a free state than considerably smaller DAU molecule. It is possible that the mentioned AMD centres belonging to the penta-peptide rings are less accessible for contacts with water molecules than keto- and oxi-groups of DAU, protruding into the solution (Fig.1). According to the hydration degree, NOG and NOV molecules have intermediate position. 
Calculated values of hydration indexes $( \pm S D)$ and their changes upon complexation of BAC and DNA

\begin{tabular}{c|c|c|c|c|c|cc|cc}
\hline Ligand & $N_{L}$ & $N_{\mathrm{DNA}}$ & $N_{\mathrm{DNA}^{*}}$ & $\Delta N_{c}$ & $N_{\mathrm{DNA}-\mathrm{C}}$ & $N_{L-C}$ & $\Delta N_{i}$ & $\Delta N$ \\
\hline AMD & $11,8 \pm 1,7$ & & $170 \pm 3$ & 2,1 & $154 \pm 5$ & $10,4 \pm 1,6$ & $-15,2$ \\
DAU & $12,4 \pm 2,2$ & & $170 \pm 3$ & 2,0 & $165 \pm 4$ & $8,3 \pm 1,3$ & $-7,5$ & $-13,1$ \\
EB & $5,9 \pm 1,0$ & & $171 \pm 4$ & 3,1 & $166 \pm 5$ & $2,5 \pm 0,8$ & $-5,9$ & $-2,8$ \\
NOG & $10,8 \pm 1,9$ & $168 \pm 5$ & $169 \pm 4$ & 0,7 & $158 \pm 5$ & $8,0 \pm 1,4$ & $-13,3$ & $-12,6$ \\
NOV & $8,8 \pm 2,1$ & & $170 \pm 3$ & 2,0 & $166 \pm 5$ & $6,7 \pm 1,8$ & $-4,6$ & $-2,6$ \\
PF & $6,4 \pm 1,0$ & & $171 \pm 4$ & 3,0 & $164 \pm 5$ & $4,1 \pm 0,7$ & $-6,3$ & $-3,3$ \\
\hline
\end{tabular}
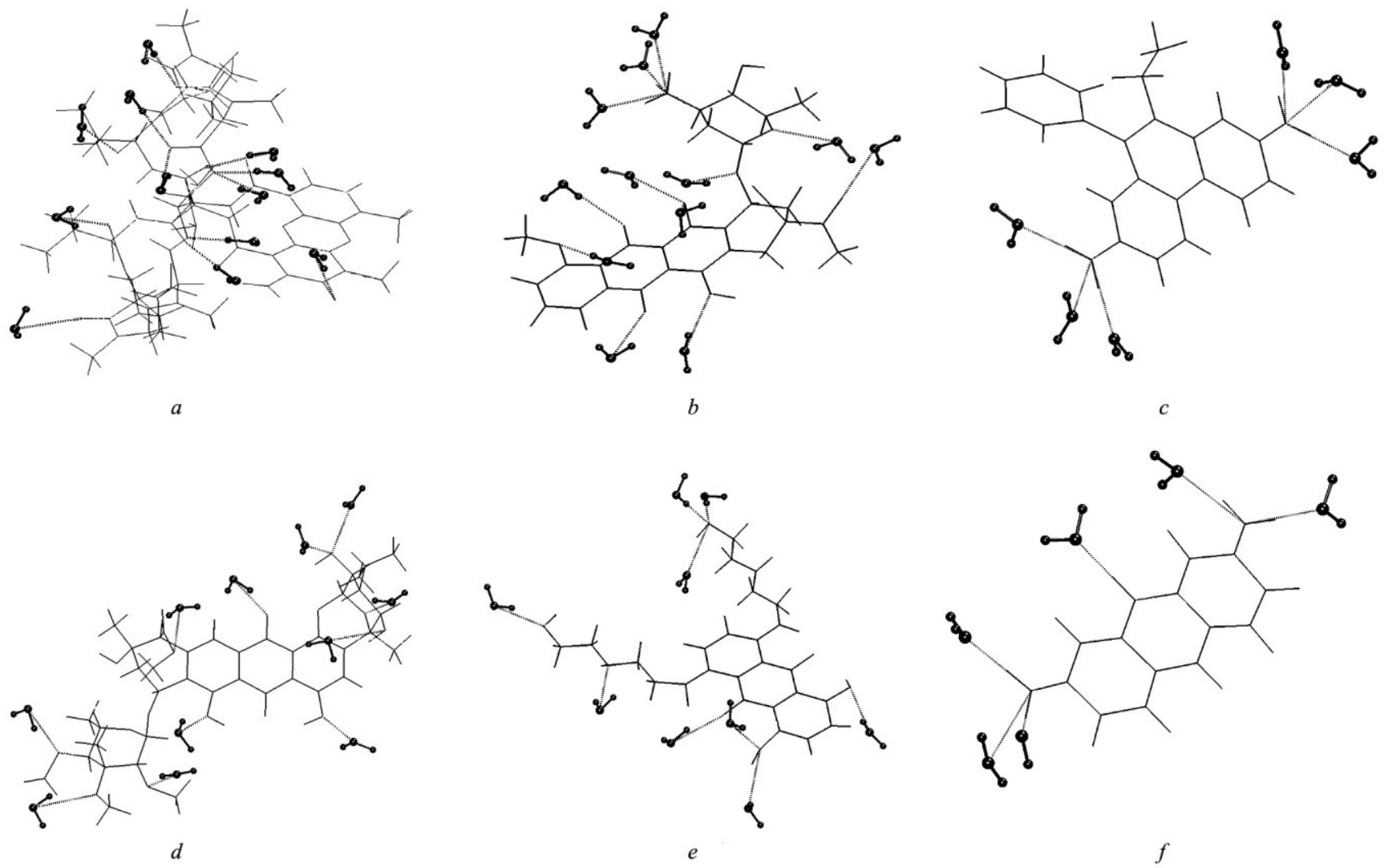

Fig. 2. Hydration of free ligands, calculated by molecular dynamics simulation: actinomycin D $(a)$, daunomycin $(b)$, ethidium bromide $(c)$, nogalamycin $(d)$, novantrone $(e)$, and proflavine $(f)$

The data, presented in Table, evidence that the change in hydration index $N_{D N A}$ in the process of DNA untwisting is positive $\left(\Delta N_{u}>0\right)$, which is quite expected as it means uptake of water molecules. It is noteworthy that the mentioned increase in accessibility of hydrate-active groups for water molecules is also accompanied with the increase in the solvent-accessible surface area of untwisted DNA
( $\triangle \mathrm{SASA}), \Delta A_{s}>0$, calculated in the work [8]. However, no vivid correlation between them was observed.

Change in hydration at intercalation. At the stage of insertion of all investigated ligands, the change in hydration index is negative $\Delta N_{i}<0$, i.e. there is release of water molecules (Table). The highest dehydration of DNA duplex is caused by AMD and NOG molecules; this fact is related to considerable screening of DNA 


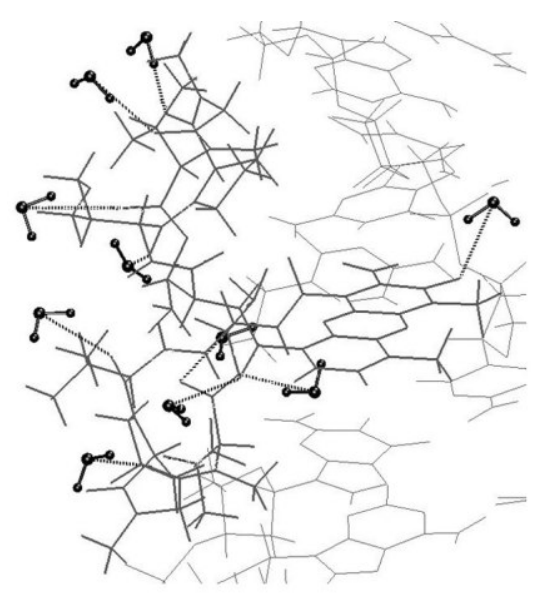

a

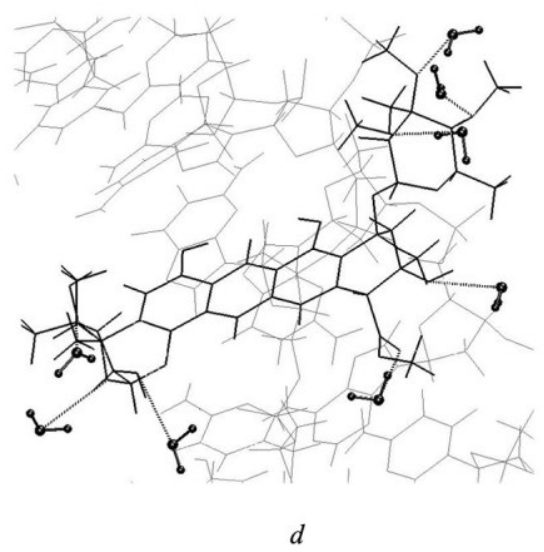

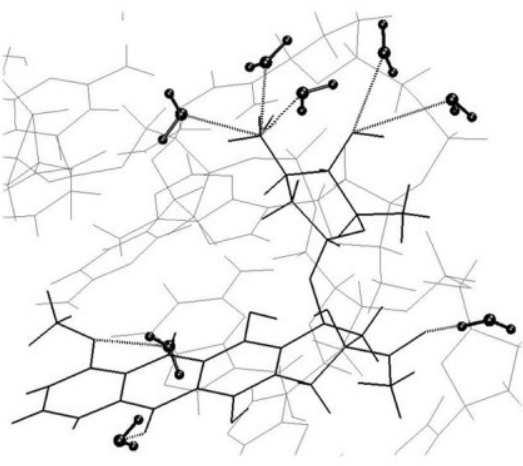

$b$

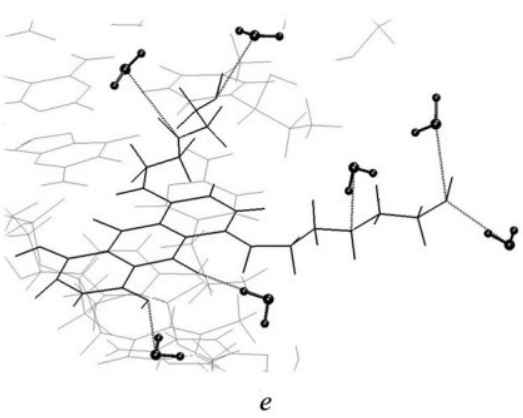

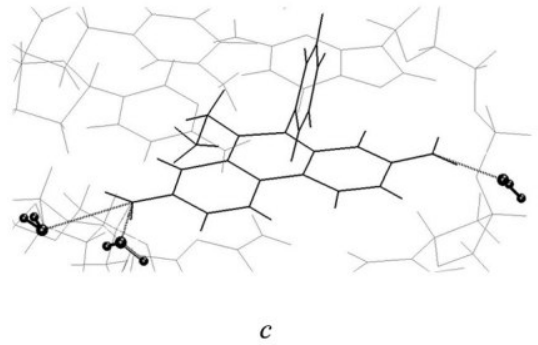

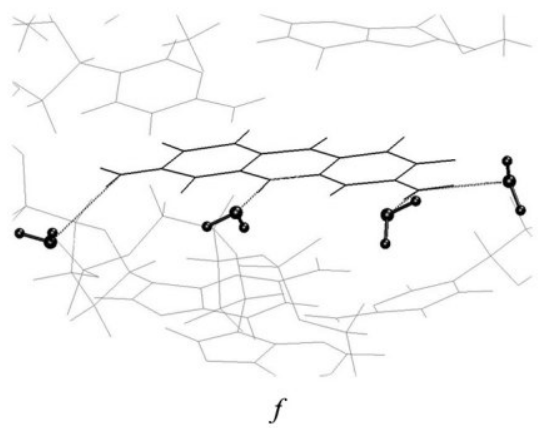

Fig. 3. Hydration of ligands in the complexes with duplex DNA, calculated by molecular dynamics simulation: actinomycin D (a), daunomycin $(b)$, ethidium bromide $(c)$, nogalamycin $(d)$, novantrone $(e)$, and proflavine $(f)$

surface from water environment by their bulky side groups (Fig.3).

The overall change in hydration in the whole process of intercalation $\Delta N$ is negative, which is another evidence to the release of water molecules (Table). Here a series of $\Delta N$ is in good agreement with the stage of ligand insertion $\Delta N_{i}(r=0.989)$, besides, there is evident correlation $(r=0.91)$ between the values of $\Delta N_{i}$ and changes in SASA upon insertion $\Delta A_{i}$, calculated in [8].

The most important result, presented in Table, is the fact that the change in hydration index $\Delta N$ of intercalation process turned out to be negative for all the investigated ligands without any exception, i.e. there is release of at least $\Delta N$ water molecules upon binding. It should be noted that the obtained values $N$ and $\Delta N$ for binding DAU to DNA are in good quantitative agreement with the results of [16]. The hydration index is not an unambiguous measure of changes in the structure of hydration shell, as it evidently characterizes only hydration of the hydrate-active groups of investigated molecules. At the same time, according to the authors of [17], it is the most strongly-bound water molecules of the nearest hydration shell that determine experimentally measurable hydration parameters. The disruption of a hydration shell may be also characterized by changes in the molecule solvent-accessible surface area ( $\triangle \mathrm{SASA})$, which was analyzed in detail in [8] for the ligands under investigation. It was shown that $\triangle$ SASA is a direct evidence of the decrease in hydration at intercalation. Therefore, two main factors, characterizing the change in water environment in both explicit $(\Delta N)$ and implicit ( $\triangle \mathrm{SASA}$ ) forms, testify to 
the release of water molecules upon intercalation. This conclusion is in good agreement with the results, obtained by other authors by methods of molecular simulation (for instance, see the works $[15,16,18]$ ).

The known experimental investigations on hydration change upon the formation of complexes of intercalators and nucleic acids may be divided conditionally into two main groups.

The first group of works was performed by volumetry (densimetry) methods [19-22] and infrared spectroscopy [18]. In all these works the authors come to the conclusion that upon the binding of DNA and aromatic ligand the complex hydration is less than that of the original components in free state, i.e. some amount $(\Delta N<0)$ of water molecules of hydration shells is displaced to the solution. Thus, this result is in agreement with the conclusions, obtained in the present work and by other authors using molecular simulation.

The second group is based on the results of osmometry, first published by the authors of $[5,7]$ for $\mathrm{EB}$, propidium iodide, DAU, doxorubicin, $\mathrm{PF}$ and AMD analogue, which have led to a surprising conclusion: the complex was hydrated more than its components in free state, i.e. upon complexation some water molecules are uptaken into the hydration shell of the complex from the solution. Therefore, $\Delta N>0$ for all the molecules (except EB). These results were confirmed by the osmometry method in earlier investigations on binding DNA to non-aromatic compounds - groove binders like netropsin [23] and DAPI $[17,23]$ - causing additional uptake, not release, of water in the complex. Parallel investigation of these and other types of groove binders using molecular dynamics simulation [24] and volumetry [19, 22] has led to an opposite result again - binding is accompanied with water displacement, not uptake. Therefore, the problem of hydration is beyond the class of solely aromatic compounds, it seems to be a general issue for ligand-DNA systems.

There are two points, which can be highlighted from the abovementioned analysis of the changes in water environment upon complexation of BAC and DNA.

1. None of the works, known to us, which were performed by two mutually exclusive methods, gave interpretation of the evident discrepancy, although in many cases authors acknowledge the very fact of discrepancy. The attempt of indirect interpretation was made in [17], where the authors assumed that methods of osmometry and volumetry measure bound water of different quality. In [21] the authors made an artificial adjustment of the results of volumetry and osmometry upon complexation excluding out of consideration the hydration of ligand itself (see Table 3 in work [21]) which is obviously incorrect. However, all this neither clears out the situation nor gives any reason to prefer one of these methods.

2. The conclusions on uptake of water molecules upon ligand binding result solely from the osmometry method and are not proven by any other available method. It brings an inevitable question: whether the results of osmometry may reflect the peculiarities of the measurement method itself, not the nature of the process ? It would be appropriate to consider the only result, obtained by the osmometry method [3], when the water release was revealed instead of uptake upon binding AMD analogue to DNA, as this result is in agreement with both the data of the present work and the data obtained by other methods. The methodological part of this work was strongly criticized in [7], where the opposite result on water uptake upon AMD intercalation was obtained by the same method. In particular, the authors declare unsuitability of the two-site model for obtaining the complexation constants, that, according to their opinion, resulted in incorrect conclusion in [3]. We think that this statement is rather ambiguous, as the majority of investigated aromatic ligands demonstrate two types of binding to duplex DNA [25], moreover, the concentration ratio of complexes of different types may vary significantly in the presence of osmolytes. Leaving aside the details of this issue, we consider it noteworthy that the conclusions based on osmometry method might vary significantly depending on a priori assumed character of ligand binding to DNA in the model. This specificity is a considerable hindrance to the application of osmometry, as determination of the character of binding to DNA is usually an independent task.

In general, we believe that modern level of comprehension of the hydration parameters measured by both volumetry (densimetry) and osmometry gives no ground to prefer one of them. Nevertheless, the 
analysis conducted allowed us to favour the concept of displacement of water upon complexation rather than water uptake, at least due to the fact that water release is confirmed by different independent methods of analysis. However, as far as we know there is one more feature of osmometry method not mentioned before.

The determination of character of changes in water environment upon complexation by osmometry method is based on the effect of decrease in water activity due to introduction of osmolytes (sucrose, betaine, etc.) The introduction of osmolytes is equivalent to change in water "concentration" that allows quantitative evaluation of the change in bound water, $\Delta N$ from the equation [7]

$$
\frac{\partial \ln \left(K_{s} / K_{0}\right)}{\partial[O s m]}=-\frac{\Delta N}{55,5}
$$

where $K_{s}$ and $K_{0}$ - constants of ligand complexation in the presence and absence of osmolyte; [Osm] osmolyte concentration.

In our opinion, the use of equation (3) for the analysis of change in hydration in processes of complexation is not correct because of the next reason. The introduction of osmolyte means that the system becomes a four-component one (water-osmolyte-DNA-ligand). The calculation of constant Ks is usually conducted in the framework of the standard McGhee-von Hippel model, derived in the assumption of a three-component solution (water-DNA-ligand). If the water-osmolyte system is viewed as a one-component system (changed water with decreased activity), the application of McGhee-vonHippel's model is really possible, but only in the assumption that the features of changed water remain the same in complexation process. However, it seems to us that it is not applicable in the standard osmometry method, utilized in the works [5, 7]. Osmolytes belong to the class of compounds, breaking water structure (see review [26]). It means that the process of either release or uptake of water upon ligand-DNA complexation will also depend on the concentration of osmolyte itself and the degree of water order close to it. In other words, $K_{s}$ parameter in (3) indirectly contains just entropic contribution from water-osmolyte interaction; therefore, $\Delta N$ also contains information about the change in water environment both at formation of ligand-DNA complex and in environment of the osmolyte itself. In simpler interpretation this effect comes from the fact that in order to find $\Delta N$ parameter in a four-component system the equation (3) has $K_{s}$ parameter, measured pertaining to the three-component system, which is not methodologically correct. It is noteworthy that while justifying osmometry method, the authors of [5] refer to an analogical and generally recognized way of determining ion contribution into the processes of complexation, based on the expression, similar to (3), and using titration of ion concentration. Ions of metals do not create a cavity like osmolytes do, i.e. they do not change water structure to the same degree, as osmolytes, therefore, this method is quite appropriate for ion contribution, but incorrect for osmometry.

Thus, the fundamental conclusion of this work is justification of the fact of release of water molecules upon binding of aromatic ligands to DNA, and the suggestion on inappropriateness of using osmometry method in the analysis of changes in water environment in reactions of complexation. This conclusion eliminates principal contradiction in literature data pertaining to the role of water in the binding of ligands to DNA.

\section{В. В. Костюков, Н. М. Хомутова, М. П. Евстигнеев}

Изменение гидратации при комплексообразовании ароматических лигандов с ДНК: моделирование методом молекулярной динамики

Резюме

Цель. Исследование изменения гидратации при образовании комплексов с ДНК ароматических биологически активных соединений (БАС): антибиотиков актиномицина D, дауномицина, ногаламицина, новантрона и мутагенов бромистого этидия и профлавина. Методы. Молекулярная динамика. Результаты. Вычислены гидратационные индексы для двуспиральной ДНК и лигандов в свободном состоянии и в составе комплекса. Проведен критический анализ современных представлений об изменении водного окружения при связывании с ДНК ароматических лигандов. Выводы. Показано, что при взаимодействии ароматических БАС с ДНК происходит значительное (от 2,6 для новантрона до 13,1 для актиномицина D) высвобождение молекул воды гидратных оболочек с разрывом водородных связей.

Ключевые слова: двуспиральная ДНК, ароматический лиганд, гидратационный индекс, высвобождение воды. 


\section{В. В. Костюков, Н. М. Хомутова, М. П. Євстигнєєв}

Зміна гідратації при комплексоутворенні ароматичних лігандів з ДНК: моделювання методом молекулярної динаміки

Резюме

Мета. Дослідження зміни гідратаиії при утворенні комплексів з ДНК ароматичних біологічно активних сполук (БАС): антибіотиків актиноміцину D, дауноміцину, ногаламіцину, новантрону $i$ мутагенів бромистого етидію $i$ профлавіну. Методи. Молекулярна динаміка. Результати. Обчислено гідратаційні індекси для двоспіральної ДНК і лігандів у вільному стані та у складі комплексу. Проведено критичний аналіз сучасних уявлень щодо зміни водного оточення при зв'язуванні з ДНК ароматичних лігандів. Висновки. Показано, ще при взаємодії ароматичних БАС з ДНК відбувається значне (від 2,6 для новантрону до 13,1 для актиномічину D) вивільнення молекул води гідратних оболонок з розривом водневих зв'язків.

Ключові слова: двоспіральна ДНК, ароматичний ліганд, гідратаційний індекс, вивільнення води.

\section{REFERENCES}

1. Brana M.F., Cacho M., Gradillas A., de Pascual-Teresa B., Ramos $A$. Intercalators as anticancer drugs // Curr. Pharm. Des.-2001.-7, N 17.-P. 1745-1780.

2. Haq I. Thermodynamics of Drug-DNA interactions // Arch. Biochem. Biophys.-2002.-403, N 1.-P. 1-15.

3. Neto J. R., Colombo M. F. Water regulation of actinomycin-D binding to DNA: the interplay among drug affinity, DNA long-range conformation, and hydration // Biopolymers.2000.-53, N 1.-P. 46-59.

4. Kostjukov V. V., Lantushenko A. O., Davies D. B., Evstigneev $M$. $P$. On the origin of the decrease in stability of the DNA hairpin d(GCGAAGC) on complexation with aromatic drugs // Biophys. Chem.-2007.-129, N 1.-P. 56-59.

5. Yu H. J., Ren J. S., Chaires J. B., Qu X. G. Hydration of drugDNA complexes: greater water uptake for adriamycin compared to daunomycin // J. Med. Chem.-2008.-51, N 19.P. 5909-5911.

6. Kostjukov V. V., Khomytova N. M., Evstigneev M. P. Partition of thermodynamic energies of drug-DNA complexation // Biopolymers.-2009.-91, N 9.-P. 773-790.

7. Qu X., Chaires J. B. Hydration changes for DNA intercalation reactions // J. Am. Chem. Soc.-2001.-123, N 1.-P. 1-3.

8. Kostjukov V. V., Khomytova N. M., Lantushenko A. O., Evstigneev $M$. $P$. Hydrophobic contribution to the free energy of complexation of aromatic ligands with DNA // Biopolym. cell.-2009.-25, N 2.-P. 133-141.

9. Berman H. M., WestbrookJ., Feng Z., Gilliland G., Bhat T. N., Weissig H., Shindyalov I. N., Bourne P. E. The protein data bank // Nucl. Acids Res.-2000.-28, N 1.-P. 235-242.

10. Kostjukov V. V., Khomytova N. M., Davies D. B., Evstigneev $M$. $P$. Electrostatic contribution to the energy of binding of aromatic ligands with DNA // Biopolymers.-2008.-89, N 8.P. 680-690.

11. Brunger A. T. X-PLOR. A system for X-ray crystallography and NMR.-Yale: Univ. Press, 1992.-382 p.
12. Chalikian T. V., Sarvazyan A. P., Breslauer K. J. Hydration and partial compressibility of biological compounds // Biophys. Chem.-1994.-51, N 2.-P. 89-109.

13. Teplukhin A. V., Poltev V. I., Chuprina V. P. Dependence of the hydration shell structure in the minor groove of the DNA double helix on the groove width as revealed by Monte Carlo simulation // Biopolymers.-1991.-31, N 12.-P. 1445-1453.

14. Reha D., Kabelac M., Ryjacek F., Sponer J., Elstner M., Suhai S., Hobza P. Intercalators. 1. Nature of stacking interactions between intercalators (Ethidium, Daunomycin, Ellipticine, and 4'6-diaminide-2-phenylindole) and DNA base pairs // J. Amer. Chem. Soc.-2002.-124, N 13.-P. 3366-3376.

15. Baginski M., Fogolari F., Briggs J. M. Electrostatic and nonelectrostatic contributions to the binding free energies of anthracycline antibiotics to DNA // J. Mol. Biol.-1997.-274, N 2.-P. 253-267.

16. Mukherjee A., Lavery R., Bagchi B., Hynes J. T. On the molecular mechanism of drug intercalation into DNA: a simulation study of the intercalation pathway, free energy, and DNA structural changes // J. Am. Chem. Soc.-2008.-130, N 30.P. 9747-9755.

17. Degtyareva N. N., Wallace B. D., Bryant A. R., Loo K. M., Petty J. T. Hydration changes accompanying the binding of minor groove ligands with DNA // Biophys. J.-2007.-92, N 3.-P. 959-965.

18. Maleev V., Semenov M., Kruglova E. B., Bolbukh T., Gasan A., Bereznyak E., Shestopalova A. Spectroscopic and calorimetric study of DNA interaction with a new series of actinocin derivatives // J. Mol. Struct.-2003.-645, N 2.-P. 145158.

19. Chalikian T. V., Breslauer K. J. Volumetric properties of nucleic acids // Biopolymers.-1998.-48, N 4.-P. 264-280.

20. Marky L. A., Macgregor R. B. J. Hydration of dA.dT polymers: role of water in the thermodynamics of ethidium and propidium intercalation // Biochemistry.-1990.-29, N 20.P. 4805-4811.

21. Han F., Chalikian T. V. Hydration changes accompanying nucleic acid intercalation reactions: volumetric characterizations // J. Amer. Chem. Soc.-2003.-125, N 24.-P. 72197229 .

22. Shi X., Macgregor R. B. J. Volume and hydration changes of DNA-ligand interactions // Biophys. Chem.-2007.-125, N 2.-P. 471-482.

23. Sidorova N. Y., Rau D. C. The osmotic sensitivity of netropsin analog binding to DNA // Biopolymers.-1995.-35, N 4.P. 377-384.

24. Shaikh S. A., Ahmed S. R., Jayaram B. A molecular thermodynamic view of DNA-drug interactions: a case of 25 minorgroove binders // Arch. Biochem. Biophys.-2004.-429, N 1.P. 81-99.

25. Baranovsky S. F., Bolotin P. A., Evstigneev M. P., Chernyshev D. N. Complexation of heterocyclic ligands with DNA in aqueous solution // J. Appl. Spectrosc.-2008.-75, N 2.P. 242-249.

26. Zavitsas A. A. Properties of water solutions of electrolytes and nonelectrolytes // J. Phys. Chem. B.-2001.-105, N 32.P.7805-7817.
UDC 577.113:577.32

Received 20.07.09 